\title{
Product Placement Strategy in the Business Market Competition: Studies of Fast Moving Consumer Goods
}

\author{
R. Agus Trihatmoko (Corresponding author) \\ Doctor Management, Faculty of Economics, and Graduate Program \\ University of Surakarta, Surakarta, Indonesia \\ E-mail: agustricentre@gmail.com \\ Roch Mulyani \\ Doctor Management, Faculty of Economics, and Graduate Program \\ University of Surakarta, Surakarta, Indonesia \\ E-mail: mulyaniargaa@gmail.com
}

\author{
Niki Lukviarman \\ Professor of Corporate Governance, Faculty of Economics \\ Andalas University, Padang, Indonesia \\ E-mail: lukviarman@gmail.com
}

Received: April 25, 2018 Accepted: May 21, 2018 Published: June 2, 2018

doi:10.5296/bmh.v6i1.13239 URL: http://dx.doi.org/10.5296/bmh.v6i1.13239

\begin{abstract}
The phenomenon of distribution intensity has received little attention in academic research, particularly in its relation to the distribution of Fast Moving Consumer Goods (FMCG). This paper aimed at exploring distribution management practices that is appropriate for describing concept and theory related to product placement in the market. The paper uses either qualitative research method as phenomenology by using the philosophy of constructivism interpretation or grounded theory by philosophy of pragmatism interpretation. The data obtained to study the development in FMCG distribution management in term of channel group of traditional markets in Indonesia. The result identifies and describes that product placement concept pervades relations among: (1) the firm's strategic policy; (2) numbers,
\end{abstract}


types, and roles of salesperson; (3) the distribution level of product; and (4) the customers' coverage expansion. Theoretically this paper proposes four typical of product placement strategies namely; trial, introduction, attacker, and leader. It might be argued that the findings of this study have constructively arranged the concept and theory of product placement as a form of its novelty. The result of the study contributes into the concept of "place" in marketing mix, along with the use of agency theory as an alternative perspective in marketing management research.

Keywords: Product Placement, Marketing Mix, Company Strategies, Channel Management, Fast Moving Consumer Goods (FMCG), Agency Theory

\section{Introduction}

Product distribution is one of popular marketing strategies and recognized as an element of marketing mix (4P's: product, price, place, promotion). Product placement (P: place) is a marketing activity in order to distribute the product for various level of channel groups. As have been argued by Evans and Berman (1992) distribution planning involves movement and ownership in a channel of distribution, which consists of channel members. Kotler and Keller (2006) state that a firm's decision related to the marketing channel system is the most critical task of management of a company. This research deals with the practice of Fast Moving Consumer Goods (FMCG) firms which is apply indirect marketing channel through establishing partnership with distributors, wholesalers, retailers, and others channels of distribution (Trihatmoko, Harsono, Wahyuni, \& Haryono, 2016b). Indirect marketing channel described practically by Kotler and Armstrong (2013) as the distribution line of consumers marketing channel.

Trihatmoko et al. (2016b) stated that the business market phenomenon of the FMCG channel group on 2010 reach more than 2.5 million stores in Indonesia. Such a channel group dominates $98.5 \%$ of business in traditional market, while the rest of businesses run their business through modern markets or outlets. Huge amount of potential market for FMCG indicates tense competition among FMCG firms in Indonesia is an effort towards achieving the level of product distribution at every type of intermediate customers. Yet, distribution intensity has received little attention in academic research (Tolba, 2011), including the distribution of FMCG in Indonesia. As argued by Ireland (2008) that distribution management within local context are across-countries and regions sharing information which contribute towards international business literatures.

Previous related studies on the aspect of management distribution conducted by Ireland (2008), Aman and Hopkinson (2010), and Tolba (2011). However, those papers are limited on situational FMCG distribution according to each research topic and/or has been not constructed the concept and theory regarding FMCG distribution management yet. In the case of Indonesia, Trihatmoko (2016) studied the FMCG distribution management conceptualization. This paper describes the subsequent work to reveals the distribution management issues that focus on FMCG product placement. Arguably, it could be considered as the originality and contributions of this paper to the literatures. 
It might be argued that the basic concept of distribution management is the product placement strategy in business market. By this point of view, the main purpose of the firms is distributing their products in order to reach potential consumers and customer for their product. In relation to the FMCG products such efforts should also consider the needs of end-user appropriately (Pongiannan \& Chinnasamy, 2014). The distributors as dealer to distribute product to various channel aimed at achieving pre-determined distribution level as set by manufacturers (Trihatmoko et al., 2016b). However, major and common obstacles may appear as argued by Kotler and Keller (2006) that the manufacturers may desire to achieve rapid market penetration through a low-price policy. Dealers or channels in contrast may prefer to work with high margins and pursue short-run profitability.

The divergence orientation of interest between manufacturers and channels as a product distributor may have an effect on the level of distribution performance in the product market. Moreover, FMCG products placement in Indonesia has been shown tight market competition, as indicated by the following characteristics (Trihatmoko, 2016): (1) geographically Indonesia is extremely large countries which consists of more than seventeen thousands scattered-islands; (2) large numbers of big and sustained firms run their business in Indonesia as main players in the industry; (3) distribution and number of market players in the form of traditional trade reaches more than two million players. Then the question arise is how and what kind of concept and theory regarding product placement strategy that appropriate to accommodate the mentioned characteristics above?

This paper aimed at exploring distribution management practices that is appropriate for describing concept and theory related to product placement in the market. The result contributes in term of marketing management advancement by considering the context of marketing-mix strategy utilizing the agency theory perspective. The result is expected to provide alternative concept and theory to be considered by managers and executives in order to determine firm's strategy on consumer marketing channel system. Proposed concept and theory is expected to contribute towards marketing management literature in the globalization era.

\section{Literature Review}

The essence of product placement in business market is the realized outcomes of efficient contract between principal firms and distributor as the main agent (Trihatmoko, 2016; Trihatmoko et al., 2016b; Bergen, Dutta, \& Walker, 1992). In this relation, Trihatmoko et al. (2016b) elaborates the relationship between principals and its main distributor concerning the strategies of product, price, place, and promotion (i.e. 4P's marketing mix). It is proposed that the agency theory will be utilized as the theoretical base of product placement and the theoretical concept refers to the marketing mix strategies.

Based on our review from previous literatures, we identify that the agency theory is rarely used as theoretical stand point in marketing management research (Bergen et al., 1992; Trihatmoko et al., 2016b). Furthermore our analysis has also found that the concept of marketing mix has not shown as the reference in most of marketing research, particularly the usage the agency theoretical perspective. As argued by Trihatmoko et al. (2016a; 2016b) and 
Trihatmoko (2016) marketing mix is still the powerful concept in defining product competition-related issues.

Due to broader scope and complexity of marketing mix concept in FMCG marketing effort, this discussion of this paper focuses on a "place" element of 4P's regarding product placement as the realized outcome from the agency theoretical perspective. The result of Trihatmoko et al. (2016b) identifies that product placement in various channel initially practiced by distributor according to determined region by principal. Pattern of distributor's product distribution in every line basically follows indirect marketing channel or consumer marketing channel system by Kotler and Armstrong (2013), Evans and Berman (1992), and the other literatures.

Review of marketing channel system indicates that product placement strategy is not popular topic in research area as research object, so as the literature review source is limited. Therefore this paper attempts to reveal the strategy on product placement related to distribution level in term of efficient contract between principal and distributor. In term achieving that effort, this paper uses qualitative method in order to obtain holistic result, so as easy to understand academically, practically, and/or pragmatically.

\section{Methods}

This qualitative study designed by using grounded theory approach with philosophy or pragmatic exegesis framework, as the follow up of previous papers which use phenomenology approach with constructivism of exegesis philosophy (Proctor, 2005; Creswell, 2009; Jonker \& Pennink, 2010; Fatchan, 2011; Saldana, 2011; Creswell, 2013; Gupta \& Awasthy, 2015; Taylor, Bogdan, \& DeVault, 2016; Trihatmoko, 2016; Kalu \& Bwalya, 2017). This paper conducted according to referral of Creswell (2013) on grounded theory and pragmatic interpretation those are: (1) researchers attempt to do abstract analysis toward one product placement phenomenon in business market competition; (2) expectation of this analysis is creating theory which is able to explain the phenomenon specifically; (3) pragmatic based interpretation is more focus on result-action, situation, and research consequence than antecedent condition; (4) basic pragmatic idea is that researcher bears fully right to select method technique, proper research procedure related to purpose of the research. In high quality or complex qualitative research researchers are allowed to combine research approach in modified way (Fatchan, 2011).

According to theoretical review on grounded and pragmatism above, thus initial data of this paper collected and processed using phenomenology approach and constructivism philosophy following Trihatmoko (2016). Research location is in marketing area of Surakarta and its satellite cities, Central of Java Province, Indonesia. This paper focuses on marketing product in traditional markets. The result indicates in detail concepts and propositions as determiner of distribution product level. Moreover Trihatmoko (2016) describes and re-analyzes within this study for conception in order to create strategy model of product placement.

Theory making of new product placement strategy practiced through data analysis in grounded theory by developing conditional matrix following Creswell (2013) which cite 
referral of Strauss and Corbin (1998). Postulated by Creswell (2013) during this time matrix approach in grounded theory was rarely conducted by researchers since the researchers suffer from lack of data, time, and sources.

Creswell (2013) notes about pragmatism basic idea which cite Cherryholmes (1992) and Murphy (1990) describe the pragmatism researchers: (1) believing the world is free from mind influence and there is the world in mind; (2) seeing what and how, and the direction of their research. According to basic idea, pragmatic interpretation allows researchers to use new terminology and describe within doing matrix analysis. This can be applied according to general characteristics that qualitative research uses complex ability skills during research process through inductive and deductive logic (Creswell, 2013).

Thus conceptualization and described theory making product placement, and methodology re-review by conducting mini-focus group discussion (Keegan, 2009). Discussion participants are the managers and distributors of distribution firms with more than ten years experiences in distributing management area for various FMCG product categories from well reputable manufacurers. Data validation is conducted by triangulation process, member check, persistence observation, trial audit, data analysis (Creswell, 2013; Fatchan, 2011; Trihatmoko et al., 2016b). Those conducted to meet confirmability and dependability procedures for qualitaitive research as practiced by Trihatmoko \& Partners.

\section{Results}

\subsection{Product Placement}

On methodology exposure mentioned that Trihatmoko (2016) reports the research regarding FMCG product placement in traditional market using phenomenology and contructivism. The result identifies that product distribution level in merchants, wholesalers, retailers $(\mathrm{A} / \mathrm{B} / \mathrm{C}$ class), special outlets and the others determined by salesperson's role. The result expresses that salespersons consist of two groups, those are distribution firm's salespersons and external salespersons such as Motoris Team, Sales Promotion Girl (SPG), Merchandiser (MD). Going deeper salespersons of distribution firms are fixed employees, while external salespersons are contract employees according to partnership contract. The total of salespersons in term of number and and hiring process depend on strategic policy defined by manufacturers or principals for all distribution firms.

The result of Trihatmoko (2016) decsribes that main job of: (1) salespersons of distribution firms are responsible for selling and distributing role to wholesalers and retailers "A/B class"; (2) Motoris Team is responsible for doing product selling and distributing for retailers " $B / C$ class" or others outlets which uncovered by distribution firm' salespersons; (3) SPG are placed at wholesalers to promote and sell the product to customers in "Retail-B/C class", and in wholesalers area; (4) MD are placed in wholesalers to set or display in one store; and (5) in one event of product launching all of salespersons team fused doing selling and distributing role to retailers "B/C class". The result formulates that salespersons role will define product distribution level according to customer coverage that already brought new product, here is the other elucidation in description below. 


\section{Ml Macrothink}

Business and Management Horizons

ISSN 2326-0297

2018, Vol. 6, No. 1

Policy of external salespersons hiring described as resource allocation by principal to their distributors. Cost of external salespersons hiring fully charged to principal, while the role distribution firm management merely as controlling and organizing role of external salesperson. Salespersons hiring policy handled by principal according to gap-ratio between number of distributor's salespersons to potential customers of the product. Phenomenon of distributor salespersons merely has customer average routinely $10 \%-12 \%$ of overall potential stores. Means for elevating product distribution according to firm's objective the firms need to add sales function whereas temporarily.

The distributor salespersons coverage leads the principal for hiring external salespersons. This strategic step practiced by firms by considering the competition at every line channel. $10 \%-12 \%$ of customers who already brought the product do not automatically distribute the product to the next channel level regarding the product competition. Phenomenon of stores as wholesalers and semi wholesalers tend to focus on fast moving products which delivering profit margin for them. The result of this paper indicates that wholesaler and semi wholesaler and retailer "A class" affect product distribution level of the product, align with number of customers who brought their product.

Textual description is above according on Trihatmoko (2016) which was firstly structurally described as premises and minor propositions research. According to textual description, furthermore could be formulated for building structural description as major proposition, and constructively illustrate on Figure 1.

P1: number and type of salespersons for product selling and distributing roles define product distribution level in various line channels.

P2: each number, type, and role of salespersons will define distributor's customer coverage expansion.

P3: determination of number, type, and role for each salespersons based on firm's strategic policy of principal and distributor.

P4: distribution level of product outcomes will expand distributor's customer coverage, and delivering multiple effects will elevate product distribution.

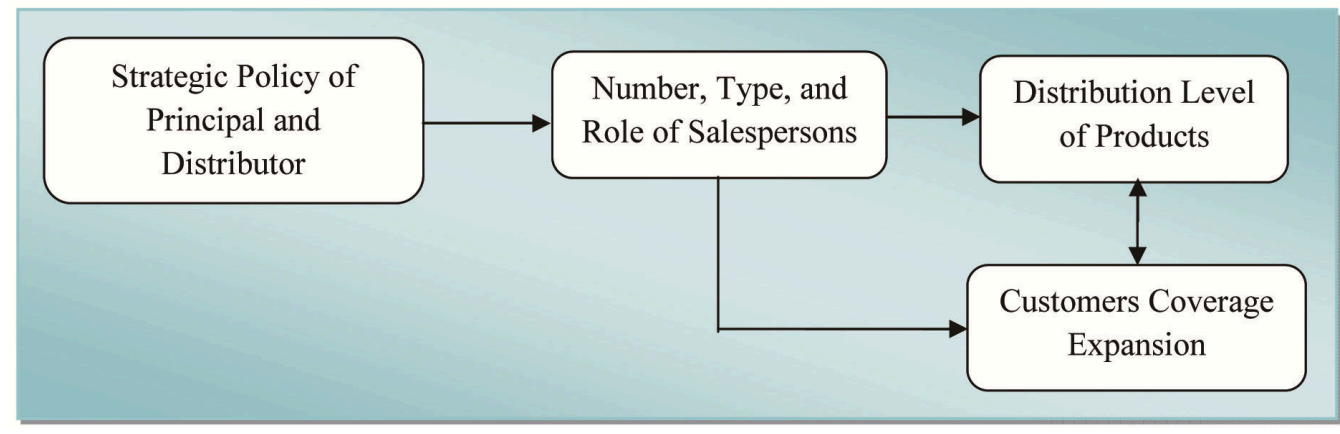

Figure 1. Product placement model

Note. development and re-design of result of Trihatmoko (2016). 


\section{Macrothink}

\subsection{Product Placement Strategy}

Conceptual result of product placement forth re-explored using grounded theory and conditional pragmatic matrix. Here are identification and theoretical description to build strategic product placement matrix.

Product placement variability concepts are direct and indirectly defined by numbers, types, and roles of salespersons. This finding could be interpreted that the drivers of product competition are number, type, and role of salespersons. Theoretically could be abstracted that firm choice in term of defining indicators product placement strategies are number salesperson and accomplished product distribution.

Abstraction of the findings above creates built theory from linkages matrix between number of salesperson and accomplishment of distribution level. The result identifies four strategies of FMCG firm in placing the product in the business market; trial, introduction, attacker and leader (Figure 2). Every strategies naming process through logic and natural thinking as real situation of business market so as pragmatically understandable.

Those strategies differently applied depend on type of item or product categorical in traditional market. The result of pragmatic thinking observation and mini-groups discussion with distributor firms informants identify some product situation and position (conditional), showed as comparison to each strategy differences (Table). Yet product brands do not disclosed for each product placement strategy considering the ethics.

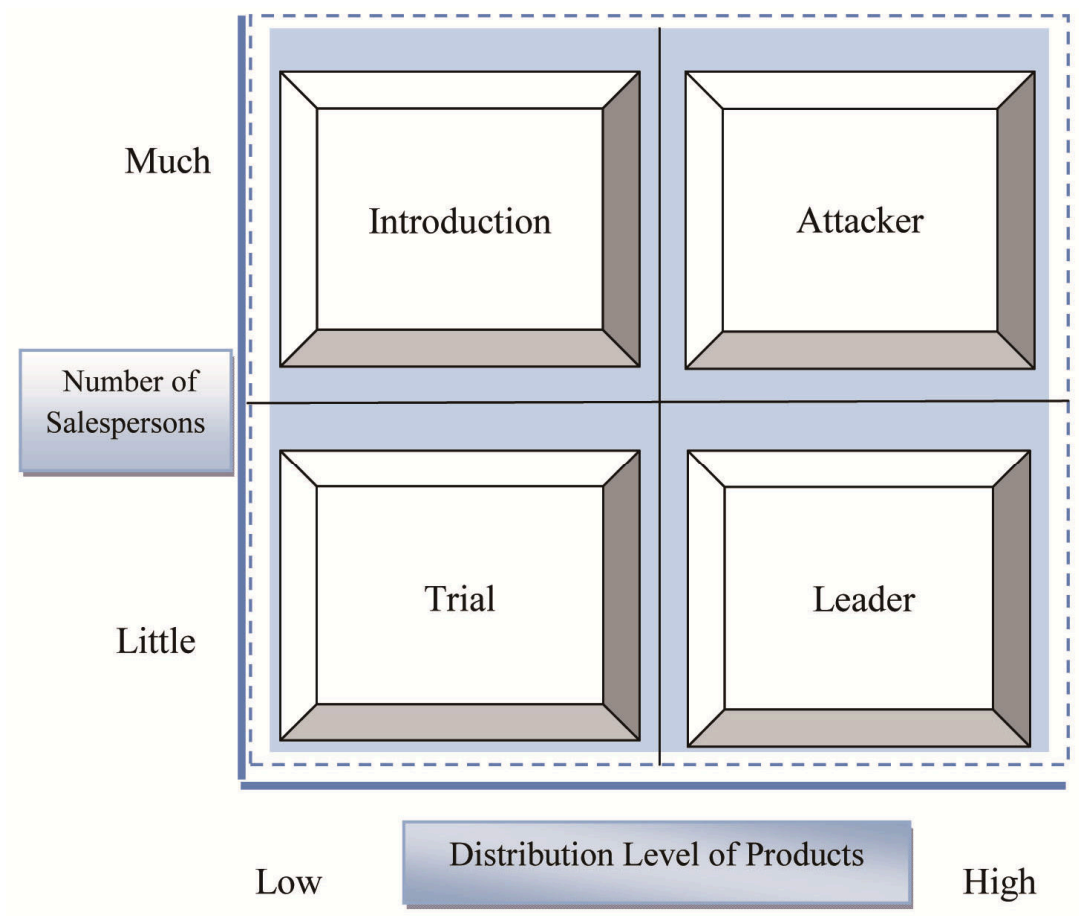

Figure 2. Product placement strategy in the business market competition 
Table 1. Identification and theme description of product placement strategy

\begin{tabular}{ccccc}
\hline Description & Trial & Introduction & Attacker & Leader \\
\hline Market Share & - & Minor & Competitive & Mayor \\
Brand & New or Existing & Existing & Existing & Existing \\
Categorical & New & New or Existing & New or Existing & Existing \\
Parent Brand & Little & Little-Moderate & Moderate-Many & Many \\
Company & Medium & Medium or Big & Big & Big \\
Market Targeting & Middle-Low & Middle-Low & Middle-Low & Middle-Low \\
\hline
\end{tabular}

Identification finding table theoretically abstracted that objective of product placement strategy is one of strategy to win or take over market share among competitor products. Strategy effectiveness will relate to some elements such as strategy related to brand creation and categorical product choices with number of brand which fused within one firm. Strategy type selected according to firm size, in term of financing capability and investment to number of salespersons hiring and selling tools. Considering that target market which aim to achieve is middle-low class which spread all over marketing area. Hence all type strategies description regarding target market is middle-low class.

\section{Discussion}

This paper novelty is building/revealing a concept and theory on product placement. Those built concept and theory proposed as development of distribution management and marketing mix concept, particularly on FMCG marketing management. Besides that, product placement concept and theory contribute for explaining or re-confirming agency theory by Bergen et al. (1992) and Trihatmoko et al. (2016b), that realized outcome of efficiency contract between principal and distributor is distribution level of product. Product placement strategy theory making describes that distribution level accomplishment potential to achieve market share accomplishment in term of product competition. This finding is in line with Trihatmoko (2016), and contributes in identifying pay-offs for principals and agents in agency theory (Bergen et al., 1992) one of them is market share accomplishment.

Product placement strategy identifies and describes that strategy tipes (trial, introduction, attacker, and leader) detected thru two indicators those are number of salespersons and product distribution level. This finding also contributes in explaining previous literatures (Kotler and Armstrong, 2013; Evans and Berman, 1992; and others) regarding determination of indirect marketing channel or consumer marketing channel system by the firms. This system considers firms capability in providing number of salesperson related to target on number and type of the customer or the merchant which sell the products. Indirect marketing channel or consumer marketing channel system possibly contributes on marketing of mass products which targeting huge market, as FMCG do. 
Theorically each type of product placement strategies related to brands and product categories, included parent brand. This finding also decribes that product placement strategy correlate with brand strategy in term of doing innovation or new product development in product competition. Brand strategy in this context consists of line extensions, brand extensions, multi brands, and new brands (Nijssen, 1999; Nijssen \& Agustin, 2005; Kotler \& Armstrong, 2013; Trihatmoko, 2016).

The paper result reveals that FMCG product placement strategy concept delivers impact on accomplishment of product distribution which compete in various channels and business market. As stated by Trihatmoko and Harsono (2017) that FMCG manufacturers impossibly market their product, without using business channel across cities in Indonesia. On the other side businessman with various levels or types such as wholesalers and semi wholesalers, retailers $\mathrm{A}, \mathrm{B}$, and $\mathrm{C}$ Class with million numbers of them. In the Indonesia economic perspective could be assessed that FMCG industries progress implicate directly on Micro Small and Medium Enterprises group. This is along with Sarangapani and Mamatha (2008) which elucidate FMCG industries have important role on development and growth of any nations, regardless their size, population, and concept of the industries.

\section{Conclusion}

The result represents that firm policies on determining numbers, types, and salespersons roles determine level of distribution and widering customer coverage, and the correlation among both of them. This finding directing first conclusion that conceptually product placement determined according to firm strategic policy objectively to achieve optimal product distribution level in business market.

Theorizing matrix of product placement reveals that strategy types trial, introduction, attacker and leader positioned based on two dimensions, those are number of salespersons and distribution level of products. Paper findings decribe that typical of product placement strategy indicators are market share, brand and product category, parent brand, company size, and market targeting of product. Those findings deliver second conclusion that theoretically the success of product placement strategy assessed according accomplishment of distribution level of product and/or market share, which relatively assessed brand and product category, parent brand, company size, and market targeting of products.

\section{Recommendation}

Paper findings propose new construct those product placement concept and theory (See, Figure 1 and 2, and Table). Implication of new built concept and theory contributes on description of realized outcomes and pay-offs for efficient contract within agency theory. Thus, research on product placement highly recommended to take into account agency theory as theoretical background of the research. The role of each channel group is manufacturer as principal, and distributor as main agent, and the other channel such as wholesaler, semi wholesaler, retailer and special outlet as subagent.

Product placement concept describes that firm strategy policy for determining number, type, and role salespersons will define level of product distribution. Strategies type trial, 
introduction, attacker, and leader are integrated strategy related to brand strategies and product category, targeting strategy, and firm size. This finding delivers signal that every types of strategy will bear a consequency on marketing expenditure, outright delivering an opportunity either on product success or failure in the market. For managers and executives higly recommend to do analysis and review carefully before deciding strategy that would be applied. i.e., doing analysis using SWOT, product costing, benchmarking of product competition, or the others which assessed more appropriate as problem solving tools and decision making tools by managers and executives.

In the discussion mentioned that product placement strategy related to innovation or the introduction of new product, either on categorical or brand. Moreover it mentioned that implication of marketing FMCG will deliver impact to small, micro, medium enterprises. It highly recommended for micro and small in trade sector to have orientation to develop their business by monitoring every new opportunity arise and fast moving products in the market.

\section{Limitations and Areas for Future Research}

The concept and theory of product placement limitedly constructed through study on mass FMCG product through distribution in traditional markets. Research object for non-FMCG or premium product or another research object will obtain different concept and theory than this paper.

Product placement concept using phenomenology approach with philosophy of interpretation constructivism so as proposed research proposition (P1-4). The result provides an opportunity for quantitative research to re-test that proposition as research hypothesis. Then product placement strategy constructed using grounded theory approach with pragmatism interpretation philosophy so as pragmatic thought analogy of the author transformed in the process of theorizing. Therefore researcher may conduct focus group discussion to re-review product placement strategy matrix. The purpose is in order the theory delivering an opportunity to develop more comprehensive and deep.

This paper slightly discuss about implication of product placement strategy related to micro economic perspective, so as the researchers in entrepreneurship area has an opportunity to conduct future study. i.e related to how do retailers grow becoming wholesaler, or how do wholesalers grow as distributor, or about how to start new business in FMCG trading sector.

\section{Acknowledgments}

The authors extend their gratitude and appreciation to the research participants of FMCG's business units in the field: manufacturers, distributors, promotional agencies, wholesalers and retailers. The gratitude also delivered to they have contributed directly or indirectly to this research, although it cannot be mentioned one by one.

\section{References}

Aman, A., \& Hopkinson, H. (2010). The Changing Structure of Distribution Channels in Pakistan. Journal of Retail \& Distribution Management, 38(5), 341-359. https://doi.org/10.1108/09590551011037572 


\section{Macrothink}

Business and Management Horizons

ISSN 2326-0297

2018, Vol. 6, No. 1

Bergen, M., Dutta S., \& Walker, Jr. O. C. (1992). Agency Relationships in Marketing: A Review of the Implications and Applications of Agency and Related Theories. Journal of Marketing, 56(3), 1-24. https://doi.org/10.2307/1252293

Creswell, J. W. (2009). Research Design. Qualitative, Quantitative and Mixed Methods Approaches. Third Edition SAGE Publication. Achmad Fawaid. 2016. Research Design. Pendekatan Kualitatif, Kuantitatif dan Mixed. Edisi Kelima. Pustaka Pelajar Yogyakarta. Indonesia.

Creswell, J. W. (2013). Qualitative Inquiry \& Research Design: Chossing Among Five Approaches (3rd ed.). SAGE Publication.

Evans, J. R., \& Berman, B. (1992). Marketing. New York, USA: Macmillan Publishing Company.

Fatchan, H. A. (2011). Metode Penelitian Kualitatif. Jenggala Pustaka Utama, Surabaya, Indonesia.

Gupta, R. K., \& Awasthy, R. (2015). Qualitative Research in Management. SAGE Publications India Pvt Ltd., New Delhi, India.

Ireland, J. (2008). Lessons for Successful BOP Marketing from Caracas's Slums. Journal of Consumer Marketing, 25(7), 430-438. https://doi.org/10.1108/07363760810915644

Jonker, J., \& Penning, B. (2010). The Essence of Research Methodology. Springer, Berlin, Germany.

Kalu, F. A., \& Bwalya, J. C. (2017). What Makes Qualitative Research Good Research? An Exploratory Analysis of Critical Elements. International Journal of Social Science Research, 5(2), 43-56. https://doi.org/10.5296/ijssr.v5i2.10711

Keegan, S. (2009). Qualitative Research. Kogan Page Ltd, London, UK.

Kotler, P., \& Armstrong, G. (2013). Principles of Marketing. Pearson Education Limited, Harlow, England.

Kotler, P., \& Keller, K. L. (2006). Marketing Management (12th ed.). Pearson Education, Inc., New Jersey, USA.

Lazuardi, A. L. (2015). Penelitian Kualitatif \& Desain Riset: Memilih di antara Lima Pendekatan. Edisi Pertama. Pustaka Pelajar Yogyakarta. Indonesia.

Nijssen, E. J. (1999). Success Factors of Line Extensions of Fast Moving Consumer Goods. Journal of Marketing, 33(5/6), 450-474. https://doi.org/10.1108/03090569910262044

Nijssen, E. J., \& Agustin, C. (2005). Brand Extension: A Manager's Perspective. Journal of Brand Management, 13(1), 33-49. https://doi.org/10.1057/palgrave.bm.2540244

Pongiannan, K., \& Chinnasamy, J. (2014). Do Advertisements for Fast Moving Consumer Goods Create Response Among the Consumers? - An Analytical Assessment with Reference 
to India. International Journal of Innovation, Management and Technology, 5(4), 249-254. https://doi.org/10.7763/IJIMT.2014.V5.522

Proctor, T. (2005). Essentials Marketing Research. Pearson Education Limited, Harlow, England.

Saldana, J. (2011). Fundamentals of Qualitative Research. Oxford University Press, Inc., New York, USA.

Sarangapani, A., \& Mamatha, T. (2008). Rural Consumer Behavior with Regard to Selected FMCG Consumption Patterns and Brand Usage: A Study. Journal of Brand Management. 5(3), 22-61.

Taylor, S. J., Bogdan, R., \& DeVault, M. L. (2016). Introduction to Qualitative Research Methods. John Wiley \& Son, Inc. Canada.

Tolba, A. H. (2011). The Impact of Distribution Intensity on Brand Preference and Brand Loyalty. Journal of Marketing Studies, 3(3), 56-66. https://doi.org/10.5539/ijms.v3n3p56

Trihatmoko, R. A. (2016). Proses Keputusan Pembelian Produk Baru oleh Grosir Industri Fast Moving Consumer Goods (FMCG) di Pasar Tradisional. Disertasi Pascasarjana Program Studi Doktor Ilmu Ekonomi, Universitas Sebelas Maret, Surakarta, Indonesia. https://digilib.uns.ac.id/dokumen/detail/57395/Proses-Keputusan-Pembelian-Produk-Baru-ole h-Grosir-Industri-Fast-Moving-Consumer-Goods-FMCG-di-Pasar-Tradisional

Trihatmoko, R. A., \& Harsono, M. (2017). Kewirausahaan: Membentuk dan Mengembangkan Unit Bisnis Handal dan Mapan. UPP STIM YKPN, Yogyakarta, Indonesia.

Trihatmoko, R. A., Harsono, M., Wahyuni S., \& Haryono, T. (2016a). Buyer-Seller Relationship Construction in The Business Buyer Behavior: Wholesaler and Distributor Fast Moving Consumer Goods (FMCG) Industry in Indonesian Market Place. International Journal of Research in Commerce \& Management, 7(5), 24-33.

Trihatmoko, R. A., Harsono, M., Wahyuni S., \& Haryono, T. (2016b). The Confine of Efficient Contract Between Principals and Distributors Perfectly Control of Marketing Mix Strategies: Channel Management Perspective of Fast Moving Consumer Goods (FMCG) Industries in Indonesian. International Journal of Research in Commerce, Economics \& Management, 6(9), 31-36.

\section{Copyrights}

Copyright for this article is retained by the author(s), with first publication rights granted to the journal.

This is an open-access article distributed under the terms and conditions of the Creative Commons Attribution license (http://creativecommons.org/licenses/by/4.0/). 